\title{
A NEW PSEUDOLEPANTHES (PLEUROTHALLIDINAE: ORCHIDACEAE) FROM NORTHWEST ECUADOR
}

\author{
Marco F. Monteros ${ }^{1,3,7}$, Luis E. Baquero ${ }^{1-3} \&$ Sebastián Vieira-Uribe ${ }^{4-6}$ \\ ${ }^{1}$ Fundación EcoMinga, 27012 de noviembre and Luis A. Martínez, Baños, Tungurahua, Ecuador. \\ ${ }^{2}$ Grupo de Investigación en Medio Ambiente y Salud BIOMAS, Carrera de Ingeniería \\ Agroindustrial y Alimentos, Facultad de Ingeniería y Ciencias Agropecuarias, \\ Universidad de Las Américas, Calle José Queri, Quito 170137, Pichincha, Ecuador. \\ ${ }^{3}$ Grupo de Investigación Dodson, Quito, Pichincha, Ecuador. \\ ${ }^{4}$ Grupo de Investigación Schultes, Fundación Ecotonos, Cali, Colombia. \\ ${ }^{5}$ Grupo de investigación en biodiversidad tropical - GIBIOT, Jardín Botánico de Medellín, Colombia. \\ ${ }^{6}$ Sociedad Colombiana de Orquideología, Medellín, Colombia. \\ ${ }^{7}$ Author for correspondence: mfmonterosa@utn.edu.ec
}

\begin{abstract}
A new species of the genus Pseudolepanthes discovered in Carchi province, northwest Ecuador, is described here. The new species is compared with P. zunagensis from which it is distinguished by a longer inflorescence with successive vinaceous or pale-yellow flowers, an elongate arcuate column, and a lip with an erect, thick, widely rectangular central callus.

Resumen. Una nueva especie del género Pseudolepanthes descubierta en la provincia del Carchi, noroccidente de Ecuador, es descrita aquí. La especie nueva se compara con P. zunagensis de la cual se distingue por tener una inflorescencia más larga con flores sucesivas, vináceas o amarillo pálido, la columna alargada, arqueada y el labelo con un callo central erecto, grueso y ampliamente rectangular.

Keywords/Palabras clave: Dracula Reserve, EcoMinga, Reserva Dracula, Trichosalpinx, Trichosalpinx pseudolepanthes
\end{abstract}

Introduction. The group of species now recognized as belonging to the genus Pseudolepanthes (Luer)Archila was initially placed in Trichosalpinx Luer, under the subgenus Tubella sect. Pseudolepanthes Luer (1986), then elevated to subgenus Pseudolepanthes Luer (1997) to accommodate all species of Trichosalpinx with small habit and non-proliferating ramicauls with lepanthiform sheaths. Morphologically, the species in the genus have successively-flowered and progressively-elongated racemes longer than the leaves, the sepals more or less membranaceus, ciliate or spiculate with lateral sepals free or variously connate below the middle; petals entire or lobed at the base; simple lips with the disc bearing a large, verrucose callus with the broad, unguiculate base firmly attached to the base of the column, the footless column is short and suberect with the anther and stigma on the front surface, except for the arcuate column of Pseudolepanthes spathulata Luer (Luer 1997, Karremans \& Vieira-Uribe 2020). Recent phylogenetic studies which included molecular data supported Pseudolepanthes as a correct genus for the species which share the characters mentioned above and also share the presence of a large, verrucose callus on the disc of the lip (Luer 1986, 1997, Bogarín et al. 2018, Bogarín et al. 2019, Karremans \& VieiraUribe 2020). Currently, Pseudolepanthes includes 10 species distributed along the Andes of Colombia and Ecuador (Luer 1997). Here we present a new species of Pseudolepanthes discovered in a poorly explored forest protected by EcoMinga Foundation in northwest Ecuador.

\section{TAXONOMIC TREATMENT}

Pseudolepanthes bihuae M.F.Monteros \& Baquero, sp. nov. (Fig. 1-2).

TYPE: Ecuador. Carchi: Reserva Dracula, 2042 m, 29 January 2019, M. Monteros 203 (holotype, QCNE!).

Diagnosis: Pseudolepanthes bihuae is most similar to P. zunagensis (Luer \& Hirtz) Archila, but it can be 
distinguished by its vinaceous or pale yellow flowers ( $v s$. orange), an elongate, arcuate column (vs. erect, stout, shorter), the lateral sepals connate in the base, slightly free to the apex and oblique ( $v s$. a shortly bifid synsepal), petals with sparsely tuberculate margins ( $v s$. entire), and a lip with an elliptical blade bent down from the middle (vs. straight, elliptical-ovoid blade), with an erect, thick, widely rectangular central callus almost as wide as the blade ( $v s$. oblong, subclavate callus much narrower than the blade).

Plant epiphytic, sympodial, caespitose herb up to $7 \mathrm{~cm}$ tall without inflorescence. Roots ca. $0.7 \mathrm{~mm}$ in diameter. Ramicauls erect, slender, stout, $3.5-4.0 \mathrm{~cm}$, enclosed by $5-6$ ciliate lepanthiform sheaths, $6-8 \mathrm{~mm}$ long. Leaf erect, coriaceous, green, suffused with purple beneath, elliptical, with two ribs parallel and close to the entire margin of the blade, the apex subacute to obtuse, emarginate, apiculate, the base cuneate into a petiole, $2.0-2.5 \times 0.9-1.2 \mathrm{~cm}$. Inflorescence a slightly sinuose, loose, successively-flowered raceme, up to $13-15 \mathrm{~cm}$ long, borne by a filiform, spiculate peduncle $0.5-1.0 \mathrm{~cm}$ long, from near the apex of the ramicaul; floral bracts spiculate, acuminate, $2-3 \mathrm{~mm}$ long; pedicels $1 \mathrm{~mm}$ long. Ovary sparsely spiculate, costate, $1 \mathrm{~mm}$ long. Sepals vinaceous or pale yellow, longspiculate abaxially, slightly carinate to carinate along the veins on the abaxial surface. Dorsal sepal narrowly ovate, attenuate, concave, 3-veined, 8.0-9.0 × $1.5 \mathrm{~mm}$. Lateral sepals narrowly ovate, attenuate, oblique, shallowly concave, connate at the base, 1-veined, 5-6 $\times 3 \mathrm{~mm}$. Petals vinaceous to pale yellow, narrowly ovate, falcate, reflexed, acute, $5 \times 1 \mathrm{~mm}, 1$-veined, with the entire margins sparsely tuberculate. Lip flamecoloured, fleshy, elliptic, with an acute apex, bent down at the middle and with a thick, widely rectangular, papillose at the apex callus, the basal half with two flaps at each side lowering in height towards the base of the lip, $3.0 \times 1.3-1.5 \mathrm{~mm}$, the blade covered with several elongate, capitate processes at the apical half, the base smooth, shallowly concave, firmly adnate to the base of the column. Column green to cream, terete, slender, elongate, arcuate, $2 \mathrm{~mm}$ long, the anther apical and stigma ventral but facing forward. Anther cap yellowish, obovate, cucullate, $0.4 \mathrm{~mm}$ long. Pollinia 2 , yellow, pyriform, attached to a detachable viscidium, $0.4 \mathrm{~mm}$ long. Capsule not seen.
Eponymy: Named in honor of Bihua Chen, founder of Cormorant Asset Management in Boston, USA. Bihua loves the natural world and has fond memories of the native orchids of her childhood home in China. She has given important help to the Rainforest Trust for its efforts to preserve this new species and other orchids in Fundación EcoMinga's Dracula Reserve.

Habitat and ecology: Pseudolepanthes bihuae is, as far as we know, endemic to northwestern Ecuador, within a region that stands out for its high diversity of orchids. Only one population of this species has been found, with plants growing as epiphytes on the trunk of a tree at $2 \mathrm{~m}$ above the ground, in extremely humid cloud forest at $2000 \mathrm{~m}$ of elevation in an unexplored area within the limits of the Dracula Reserve. Other species of the subtribe Pleurothallidinae, like Brachionidium imperiale Luer \& R.Escobar, Lepanthes generi Luer \& Hirtz and Lepanthes gloris Luer \& Hirtz, were found growing with P. bihuae. Although we compared $P$. bihuae with $P$. zunagensis, these are separated geographically; $P$. zunagensis was found in the eastcentral slopes of the Andes of Ecuador, while P. bihuae is found in the northwest Ecuadorian Andes.

Paratypes: Ecuador. Carchi: Reserva Dracula, 2042 m, 31 September 2019, M. Monteros 204 (paratype, QCNE-Spirit!). Ecuador. Carchi: Reserva Dracula, 2042 m, 31 September 2019, M. Monteros 205 (paratype, QCNE!).

Phenology: This species has always been observed blooming in its habitat throughout the year, where the humidity stays constant.

Pseudolepanthes bihuae is recognized by its vinaceous or pale yellow flowers, elongate, arcuate column, and also by its lip with an elliptical blade bent down from the middle with an erect, thick, widely rectangular central callus. Pseudolepanthes bihuae shares with $P$. zunagensis a few characteristics, such as the long spiculate, concave, ovate, acute dorsal sepal and the slender, falcate, reflexed petals, but $P$. bihuae is easily distinguished by the vinaceous or pale yellow flowers ( $v s$. orange flowers in P. zunagensis), the elongate, arcuate column ( $v s$. short, erect, stout column in P. zunagensis) and the lip with an erect, thick, widely rectangular central callus (vs. with a 


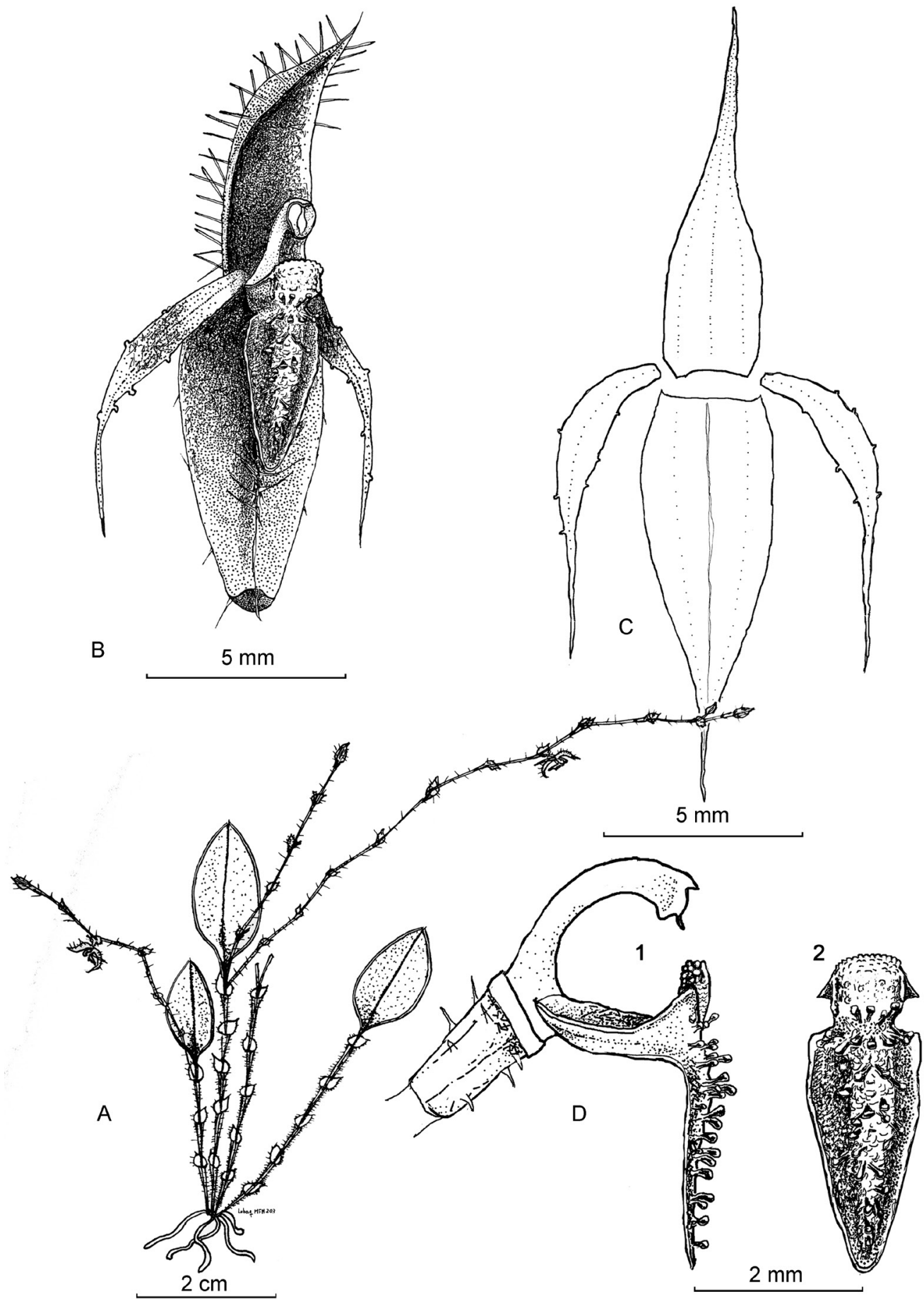

Figure 1. Illustration of Pseudolepanthes bihuae M.F.Monteros \& Baquero. A. Habit. B. Flower. C. Dissected Perianth. D1. Column and lip, lateral view. D2. Lip, frontal view. Drawn by Marco F. Monteros and Luis E. Baquero from the plant that served as the holotype. (MFM 203, QCNE). 


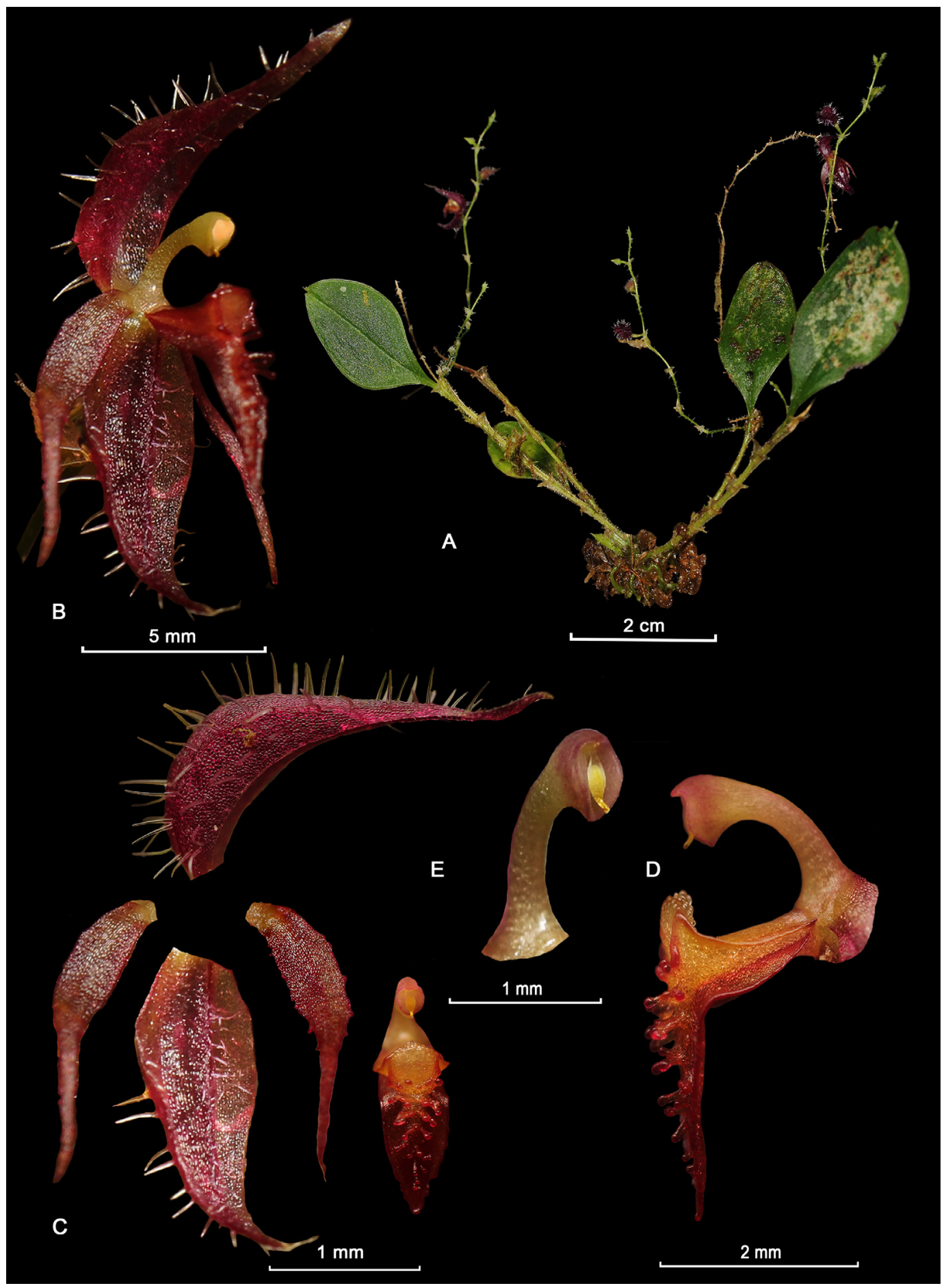

Figure 2. Lankester composite dissection plate of Pseudolepanthes bihuae M.F.Monteros \& Baquero. A. Habit. B. Flower, $3 / 4$ view. C. Dissected perianth. D. Column and lip, lateral view. E. Column and anther, $3 / 4$ view. F. Peduncle and floral bract. Photographs by Marco F. Monteros from the plant that served as the holotype. (MFM 203, QCNE). 


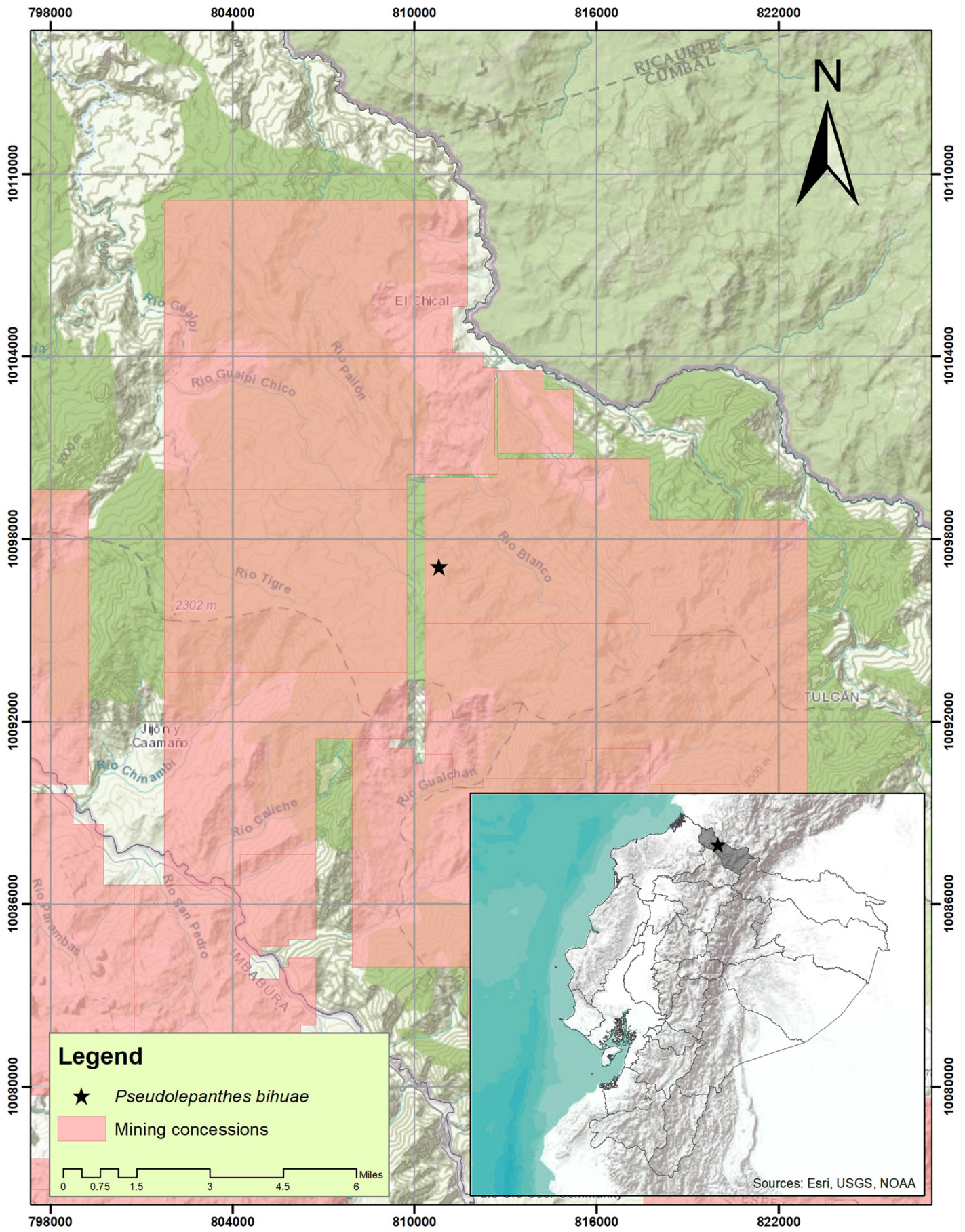

FIgURE 3. Distribution map of Pseudolepanthes bihuae M.F.Monteros \& Baquero. Distributed in Carchi province northwest of Ecuador and mining threats. Map created by Marco F. Monteros. 
verrucose callus slightly clavate at the rounded apex in P. zunagensis).

Pseudolepanthes bihuae represents the first record of the genus in northwest Ecuador. Nonetheless, most species of the Pseudolepanthes are from the western Andes of Colombia where apparently, the endemism center of this genus is located (Luer 1997). Finally, it is important to emphasize that the small population of $P$. bihuae in Ecuador is threatened, mainly by the illegal extraction of species and the mining projects that directly affect its distribution area in northwest Ecuador (Roy et al. 2018). For this reason, it is important and necessary to evaluate and categorize this species under the IUCN red list criteria (Fig. 3).

Conservation status: The principal threats to Pseudolepanthes bihuae are mining activity and illegal extraction of species. In Ecuador, the government owns the subsoil rights and has sold concessions in the Dracula Reserve to mining companies. Some of these mining concessions are becoming active now, and under Ecuadorian law they can work even in private protected areas such as the Dracula Reserve, where this species lives. Also, illegal mining and associated deforestation are becoming a problem in this area. We suggest considering this species as "Critically endangered" following criteria B1a, B1b(iii) IUCN (2012) since it has only been found at a single locality in Carchi province, in northwest Ecuador. If the mining activity is not controlled, the only population of $P$. bihuae will be strongly affected by the loss of natural forest. Therefore, this population possibly might disappear in the following years (Fig. 3).

Acknowledgments. To Fundación EcoMinga, Rainforest Trust, and University of Basel Botanical Garden for funding research on new and endangered species in northwest Ecuador, close to the Dracula Reserve, which it protects, and Universidad de Las Américas (UDLA) for funding orchid research in Ecuador. The Ministerio del Ambiente del Ecuador is acknowledged for issuing the Environmental Research Permit No. 008-2016-IC-FLO-DNB/MA.

\section{LiTERATURE CITED}

Bogarín, D., Karremans, A. P. \& Fernández, M. (2018). Genus-level taxonomical changes in the Lepanthes affinity (Orchidaceae, Pleurothallidinae). Phytotaxa, 340(2), 128-136. https://doi.org/10.11646/phytotaxa.340.2.2

Bogarín, D., Pérez-Escobar, O. A., Karremans, A. P., Fernández, M., Kruizinga, J., Pupulin, F. \& Gravendeel, B. (2019). Phylogenetic comparative methods improve the selection of characters for generic delimitations in a hyperdiverse Neotropical orchid clade. Scientific Reports, 9(1), 1-17. https://doi.org/10.1038/s41598-019-51360-0

Karremans, A. P. \& Vieira-Uribe, S. (2020). Pseudolepanthes. In: A. P. Karremans \& S. Vieira-Uribe (Eds), Pleurothallids, Neotropical jewels, volume I (pp. 251-258). Quito, Ecuador: Imprenta Mariscal.

Luer, C. A. (1986). Icones Pleurothallidinarum. I. Systematics of the Pleurothallidinae. Monographs in Systematic Botany from the Missouri Botanical Garden, 15, 65-68.

Luer, C. A. (1997). Icones Pleurothallidinarum. XV. Trichosalpinx. Monographs in Systematic Botany from the Missouri Botanical Garden, 64, 5, 105-113.

Roy, B. A., Zorrilla, M., Endara, L., Thomas, D. C., Vandegrift, R., Rubenstein, J. M. \& Read, M. (2018). New mining concessions could severely decrease biodiversity and ecosystem services in Ecuador. Tropical Conservation Science, $11,1940082918780427$.

UICN. (2012). Categorías y Criterios de la Lista Roja de la UICN: Versión 3.1. Segunda edición. Gland, Suiza y Cambridge, Reino Unido: UICN. vi + 34pp. Originalmente publicado como IUCN Red List Categories and Criteria: Version 3.1. Second edition. (Gland, Switzerland and Cambridge, UK: IUCN, 2012). 